\title{
Temperature Effects on Biomass and Regeneration of Vegetation in a Geothermal Area
}

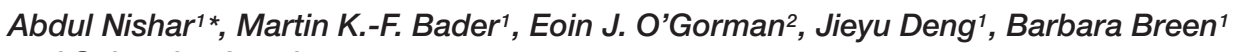 \\ and Sebastian Leuzinger ${ }^{1 *}$
}

${ }^{1}$ School of Sciences, Auckland University of Technology, Auckland, New Zealand, ${ }^{2}$ Imperial College London, London, UK

\section{OPEN ACCESS}

Edited by:

Boris Rewald,

University of Natural Resources and Life Sciences, Vienna (BOKU), Austria

Reviewed by:

Ivika Ostonen,

University of Tartu, Estonia Andong Shi,

Forschungszentrum Jülich, Germany

*Correspondence: Abdul Nishar

abdul_nishar@xtra.co.nz

Sebastian Leuzinger

sebastian.leuzinger@aut.ac.nz

Specialty section: This article was submitted to Functional Plant Ecology, a section of the journal Frontiers in Plant Science

Received: 19 August 2016 Accepted: 09 February 2017

Published: 07 March 2017

Citation:

Nishar A, Bader MK-F

O'Gorman EJ, Deng J, Breen B and Leuzinger S (2017) Temperature Effects on Biomass and Regeneration of Vegetation in a Geothermal Area.

Front. Plant Sci. 8:249 doi: $10.3389 /$ fpls.2017.00249
Understanding the effects of increasing temperature is central in explaining the effects of climate change on vegetation. Here, we investigate how warming affects vegetation regeneration and root biomass and if there is an interactive effect of warming with other environmental variables. We also examine if geothermal warming effects on vegetation regeneration and root biomass can be used in climate change experiments. Monitoring plots were arranged in a grid across the study area to cover a range of soil temperatures. The plots were cleared of vegetation and root-free ingrowth cores were installed to assess above and below-ground regeneration rates. Temperature sensors were buried in the plots for continued soil temperature monitoring. Soil moisture, $\mathrm{pH}$, and soil chemistry of the plots were also recorded. Data were analyzed using least absolute shrinkage and selection operator and linear regression to identify the environmental variable with the greatest influence on vegetation regeneration and root biomass. There was lower root biomass and slower vegetation regeneration in high temperature plots. Soil temperature was positively correlated with soil moisture and negatively correlated with soil pH. Iron and sulfate were present in the soil in the highest quantities compared to other measured soil chemicals and had a strong positive relationship with soil temperature. Our findings suggest that soil temperature had a major impact on root biomass and vegetation regeneration. In geothermal fields, vegetation establishment and growth can be restricted by low soil moisture, low soil pH, and an imbalance in soil chemistry. The correlation between soil moisture, $\mathrm{pH}$, chemistry, and plant regeneration was chiefly driven by soil temperature. Soil temperature was negatively correlated to the distance from the geothermal features. Apart from characterizing plant regeneration on geothermal soils, this study further demonstrates a novel approach to global warming experiments, which could be particularly useful in low heat flow geothermal systems that more realistically mimic soil warming.

Keywords: global warming experiment, soil warming, Kunzea tenuicaulis, climate change, LASSO, Wairakei

\section{INTRODUCTION}

Soil temperature plays an important role in many of the abiotic and biotic processes that are integral to plant growth (Oelke and Zhang, 2004), above and below ground biomass (Abramoff and Finzi, 2014; Munir et al., 2015), plant productivity (Luo et al., 2009), nutrient uptake (Rustad et al., 2001), and diversity and distribution (Bond-Lamberty et al., 2006; 
Pickering and Green, 2009; Djebou and Singh, 2015). Changes in vegetation cover are a response resulting from both environmental and biological conditions. Several authors have reported significant relationships between temperature and vegetation indices (Zhang et al., 2004; Kumar and Shekhar, 2015; Wang et al., 2015). Moreover, soil temperature influences soil moisture levels and microbial function and productivity (Lukewille and Wright, 1997; Pregitzer and King, 2005).

It is generally found, based on field observations (Lapenis et al., 2014) and remotely-sensed data (Shen et al., 2014), that soil temperature levels vary widely across landscapes based on elevation (Balisky and Burton, 1995; Clinton, 2003) and climate (Kang et al., 2000). However, over the last 100 years, soil temperature has risen in many areas as a result of climate change (IPCC, 2013). The average global surface temperature increased by $0.74^{\circ} \mathrm{C}$ from 1906 to 2005 (IPCC, 2007) and most models predict a rise in global surface temperature of at least $1.5-2.0^{\circ} \mathrm{C}$ by the end of this century (IPCC, 2013). The increase in the surface temperature during the past century has contributed to changes in vegetation phenology, species ranges, and community composition (Walther, 2010; Villarreal and Jesus, 2012) and the projected global temperature increase will generally result in an increase in near-surface soil temperatures (Chapin and Körner, 1995; Oechel et al., 1995; Claussen et al., 1999; Betts, 2001; ACIA, 2005; Hinzman et al., 2005), affecting soil conditions (Rixen et al., 2008; Okkonen and Kløve, 2010) and vegetation structure, composition, and growth.

Warming experiments in the past have used a variety of heating methods, including electric heating (de Valpine and Harte, 2001), infrared radiation (Wan et al., 2002), reciprocal transplants (Jonasson et al., 1993), and open- and closed-top field greenhouses (Henry and Molau, 1997). These approaches obviously have their place and contribute to our understanding, but each of these methods come with their own set of limitations (Shaver et al., 2000). Geothermally-heated ecosystems have recently been identified as complementary natural warming experiments, where one can investigate long term adaptation of real-world communities across natural temperature gradients (O'Gorman et al., 2014). Typically, geothermal hotspots have been heated above ambient conditions for a very long time (Bibby et al., 1995). The levels of soil heat, steam, and gaseous output vary amongst geothermal systems (Legittimo and Martini, 1989; McGee, 1997), depending on geological structures, the depth of the magma chamber and the water table (Legittimo and Martini, 1989). The area of soil heat emissivity depends on the geothermal heat flow (Hoang, 2010) whereas the level of impact on vegetation is a function of the distance from the geothermal heat point source (Kershaw, 1985).

Although warming affects all plant life-cycle phases, plant regeneration has been suggested to be especially sensitive (Hedhly et al., 2009; Walck et al., 2011). Vegetation regeneration is a strong indicator of changes in soil conditions and an increase in soil temperature will have an adverse effect on vegetation regeneration levels (Althoff et al., 2016). Similarly, root biomass may change in response to altered environmental variables (Norby and Jackson, 2000). Soil temperature is a primary rateregulating factor (Berg et al., 1993; Kirschbaum, 1995) and an increase in soil temperature may lead to an overall reduction in root biomass (Milchunas and Lauenroth, 2001; Carón et al., 2015).

In this study we analyzed the effect of geothermal warming on vegetation by assessing plant regeneration rates and root biomass across a wide range of soil temperatures and soil chemical properties. We specifically addressed the following questions: (i) How does soil warming affect vegetation regeneration and root biomass? (ii) What set of variables (temperature, soil chemistry, and their interactions) best predicts changes in below and above ground biomass? We hypothesized that vegetation regeneration and root biomass will show a negative correlation with increasing soil temperature. Additionally, we expected soil temperature to have a far greater impact on vegetation regeneration above- and below-ground than other environmental variables.

\section{MATERIALS AND METHODS}

\section{Study Area}

The Taupo Volcanic Zone (TVZ) in the North Island of New Zealand covers an area of approximately $30 \mathrm{~km} \times 150 \mathrm{~km}$ (Soengkono, 1995; Kissling and Weir, 2005), containing 23 stable and long-lived geothermal fields (Bibby et al., 1995) with varying heat outputs (Kissling and Weir, 2005). The Wairakei-Tauhara geothermal field in particular has distinctive assemblages of plants that survive under extreme geophysical and geochemical conditions (Given, 1980; Healy, 1992; Boothroyd and Stark, 2000; Death and Death, 2006). The section of the Wairakei-Tauhara geothermal field covered by this study is referred to as the Crown Road Geothermal Area (located at $38^{\circ} 41^{\prime} 28.31^{\prime \prime} \mathrm{S} 176^{\circ} 06^{\prime}$ $\left.54.15^{\prime \prime} \mathrm{E}\right)$, covering an area of about $1 \mathrm{~km}^{2}$.

\section{Study Species}

The plant species found in the study area and studied was Kunzea tenuicaulis, a shrub in the native tea tree genus Kunzea (Myrtaceae). Kunzea tenuicaulis propagates from seeds and is endemic to active geothermal sites and its growth habit is a good indicator of soil temperature and geothermally altered soil (Smale et al., 2009). Soil temperature has the largest influence on the distribution of Kunzea tenuicaulis (Given, 1980; Martin et al., 2000) with soil acidity and chemical concentrations having minor effects (Burns and Leathwick, 1995; Burns et al., 1995; Burns, 1997).

\section{Experimental Design}

In order to determine the effects of soil temperature on above and below-ground vegetation regeneration, an experimental trial was implemented in December 2014. We delineated a grid within the study area, consisting of $18150 \mathrm{~m} \times 200 \mathrm{~m}$ blocks. We established a $0.6 \mathrm{~m} \times 0.6 \mathrm{~m}$ plot within each block to span a range of surface temperature profiles, including three ambient plots $\left(<19^{\circ} \mathrm{C}\right)$ and 15 plots in warm to hot areas $\left(24-50^{\circ} \mathrm{C}\right)$. These subsurface spot temperature measurements were taken at a depth of $15 \mathrm{~cm}$ to assist with plot allocation.

We removed all vegetation, including roots, within our $0.6 \mathrm{~m} \times 0.6 \mathrm{~m}$ plots, to allow regeneration and not just regrowth 


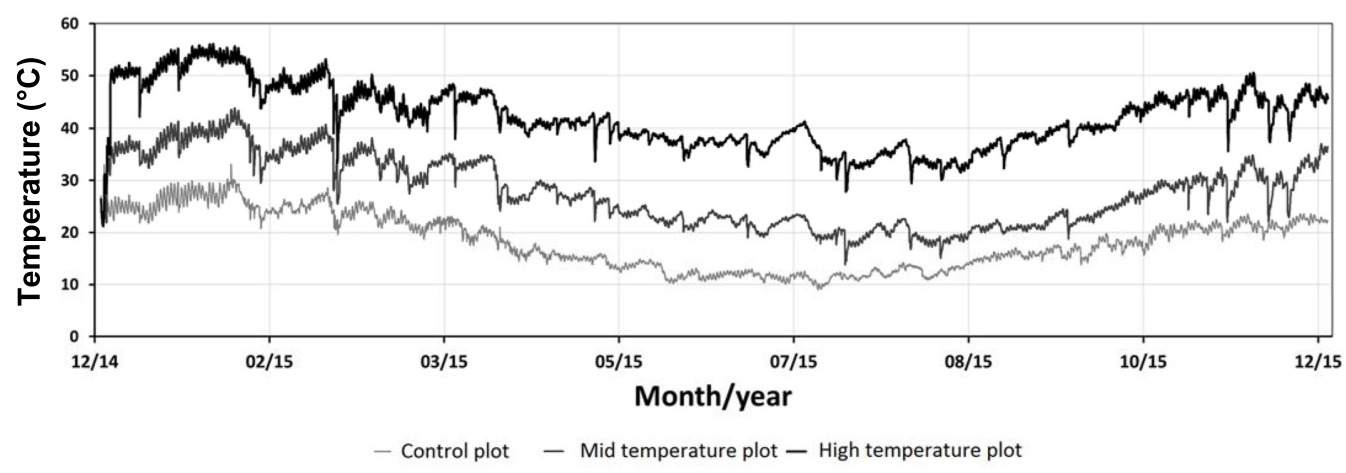

FIGURE 1 | Hourly soil temperature fluctuations at $15 \mathrm{~cm}$ depth $(n=18$, control: $n=3$, mid temperature: $n=11$, high temperature: $n=4)$, December 2014-December 2015. Data captured at Crown Road Geothermal Area.

TABLE 1 | Experimental plots with mean soil temperatures over the study period.

\begin{tabular}{lc}
\hline Control plots & Mean soil temperature $\left({ }^{\circ} \mathbf{C}\right)$ \\
\hline C2 & 16.74 \\
C3 & 17.19 \\
C1 & 19.11 \\
Mid temperature plots & \\
E3 & 19.33 \\
E7 & 24.49 \\
E4 & 25.65 \\
E5 & 26.88 \\
E6 & 27.36 \\
E13 & 29.6 \\
E9 & 30.56 \\
E2 & 30.67 \\
E15 & 36.05 \\
E8 & 37.74 \\
E11 & 37.93 \\
High temperature plots & \\
E10 & \\
E12 & 42.05 \\
E14 & 45.72 \\
E1 & 45.88 \\
\hline
\end{tabular}

to take place. The $0.6 \mathrm{~m} \times 0.6 \mathrm{~m}$ plots had $100 \%$ vegetation coverage before the experiment was set up. The vegetation-free plots were revisited on a monthly basis until December 2015 to monitor the aboveground regeneration rate as percentage cover within a $0.5 \mathrm{~m} \times 0.5 \mathrm{~m}$ area, allowing for a $0.1 \mathrm{~m}$ buffer around the perimeter of each plot (Loetsch and Haller, 1973, München, Germany; Sachtler, 1975, Merida, Venezuela-Roma, Italy). The above ground vegetation regeneration was determined by the number of new seedlings found after 12 months.

We used the ingrowth core method to quantify root growth (Bledsoe et al., 1999; Milchunas and Lauenroth, 2001). Ingrowth cores consisted of wire cylinders $(12 \mathrm{~cm}$ long, $3.5 \mathrm{~cm}$ diameter, $2 \mathrm{~mm}$ mesh size), containing root-free soil from a site within the geothermal area, with similar soil temperature. Three ingrowth cores were installed in each of the regeneration plots at the start

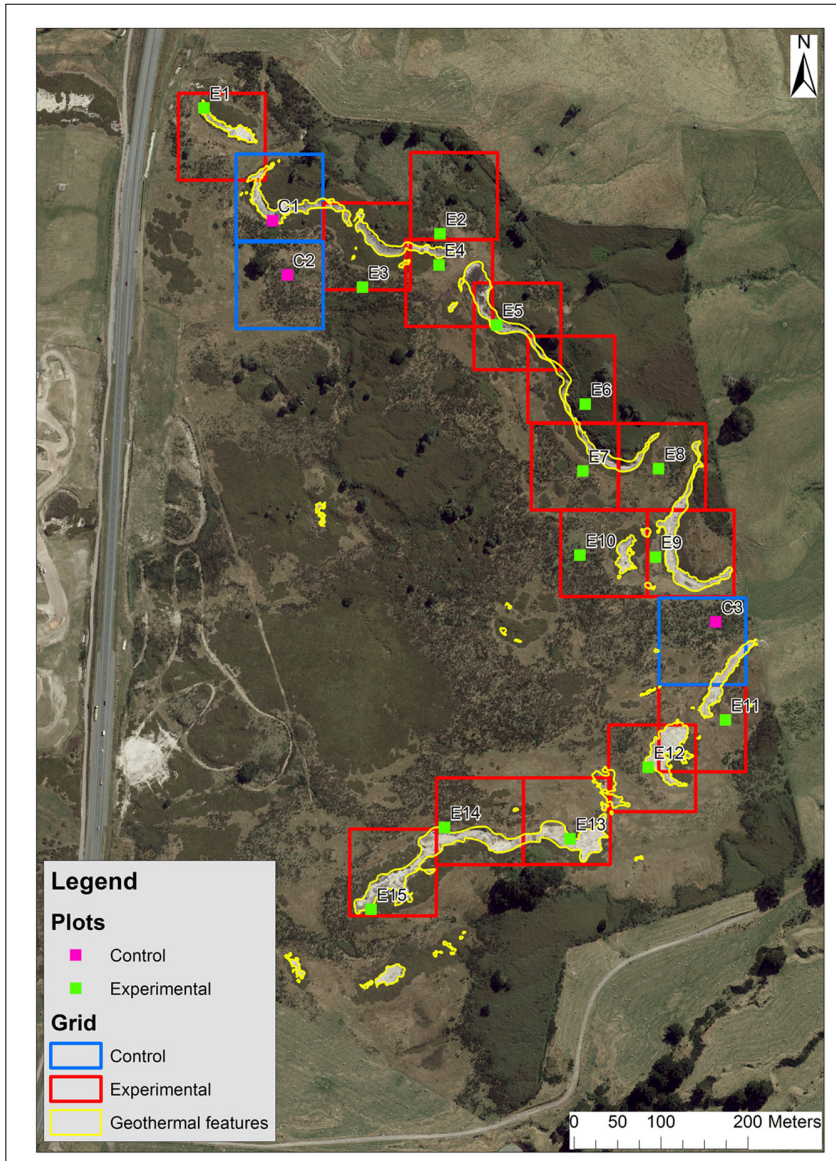

FIGURE 2 | Aerial photo of the study site, grid, and plot locations and geothermal features.

of the experiment. We used a soil corer to create a cylindrical hole in each plot, inserting the ingrowth cores three $\mathrm{cm}$ below the soil surface, and covering them with topsoil. After excavation in December 2015, the cores were transferred to the lab where the new roots were separated from the soil with sieves with 1-3 $\mathrm{mm}$ mesh size, rinsed, and set in a water bath to be 
TABLE 2 | Means and statistical parameters of major and minor soil elements from across the 18 plots, compared to control plots.

\begin{tabular}{lcccc}
\hline Element $\left(\mathbf{m g ~ k g}^{-\mathbf{1}}\right)$ & Mean & Standard error & $\boldsymbol{t}$-value & $\boldsymbol{P}$ \\
\hline $\mathrm{Ca}$ & 2.687 & 0.78 & -1.88 & 0.086 \\
$\mathrm{Fe}$ & 77.29 & 0.05 & 3.79 & 0.005 \\
$\mathrm{~K}$ & 2.216 & 2.37 & 3.1 & 0.013 \\
$\mathrm{Mg}$ & 1.787 & 3.88 & 0.99 & 0.367 \\
$\mathrm{Mn}$ & 0.615 & 3.79 & 4.08 & 0.003 \\
$\mathrm{P}$ & 5.306 & 0.68 & -0.07 & 0.813 \\
$\mathrm{~B}$ & 0.062 & 22.63 & -0.97 & 0.342 \\
$\mathrm{SO}{ }_{4}^{2-}$ & 28.28 & 0.06 & 5.94 & $<0.001$ \\
$\mathrm{Cd}$ & 0.005 & 1186.53 & 0.09 & 0.976 \\
$\mathrm{Cu}$ & 0.041 & 70.94 & -0.72 & 0.468 \\
$\mathrm{Ni}$ & 0.007 & 538.39 & 1.58 & 0.403 \\
$\mathrm{~Pb}$ & 0.288 & 12.45 & 3.28 & 0.011 \\
$\mathrm{Zn}$ & 0.11 & 33.26 & 1.19 & 0.365 \\
\hline
\end{tabular}

Data captured at Crown Road Geothermal Area.

scanned. The images captured were analyzed using WinRHIZO software (Regent Instruments, Inc., Quebec, QC, Canada), which separated them into five size classes by diameter: $0-0.5 \mathrm{~mm}$, 0.5-1 mm, 1-1.5 m, $1.5-3 \mathrm{~mm}$, and 3-4.5 $\mathrm{mm}$. The roots were measured using micrometer calipers and separated using tweezers. Once scanned, the roots were separated from water and dried at $70^{\circ} \mathrm{C}$ for $65 \mathrm{~h}$ (to constant dry weight) and weighed to determine the biomass. $65 \mathrm{~h}$ in the oven had removed all the moisture from root, any more time in the oven would have been redundant. Below ground biomass regeneration was determined by the combined biomass of all roots per plot.

\section{Environmental Variables}

Instantaneous subsurface spot temperature measurements were used to determine the high temperature plot locations at the outset of the experiment. Instantaneous subsurface spot temperature was measured in all the blocks at a depth of $15 \mathrm{~cm}$, using a Yokogawa TX10 digital thermometer (Yokogawa Electric Corporation, Musashino, Tokyo, Japan) connected to a type $\mathrm{K}$ thermocouple. Once the plots were selected, continuous soil temperature measurements were used to provide a detailed temperature profile throughout the 1-year duration of the experiment. For continuous soil temperature measurements, one Thermochron iButton (DS1921G) temperature logger (Maxim Integrated, San Jose, CA, USA) was buried in each of the 18 monitoring plots at a depth of $15 \mathrm{~cm}$ and left in place from December 2014 to December 2015. The data from the iButtons were retrieved on a monthly basis.

Soil moisture readings were taken in each of the 18 monitoring plots using a Decagon Devices ProCheck meter with a $10 \mathrm{HS}$ soil moisture sensor (Decagon Devices, Pullman, WA, USA). Soil was taken at the depth of $15 \mathrm{~cm}$ on a monthly basis (December 2014December 2016). For soil pH analysis, a soil sample was taken from each of the plots and oven-dried. In July 2016, soil was removed using a soil corer from a depth of $15 \mathrm{~cm}$. The oven-dried soil sample was mixed with deionised water (1:2.5 volumetric ratio of soil to deionised water) and was set for a day. After thorough mixing, each sample solution was measured using a $\mathrm{pH}$ meter.

Soil samples $(100 \mathrm{~g})$ were taken using a $15 \mathrm{~cm} \times 3.5 \mathrm{~cm}$ (length $\times$ diameter) soil corer from each of the 18 plots, from 0 to $15 \mathrm{~cm}$ below the surface. The soil samples were taken during July 2015. In the lab, the samples were oven-dried at $60^{\circ} \mathrm{C}$ for 3 days and ground for testing. Soil samples were tested for sulfate $\left(\mathrm{SO}_{4}{ }^{2-}\right)$, magnesium $(\mathrm{Mg})$, potassium $(\mathrm{K})$, iron $\left(\mathrm{Fe}^{2+}\right.$ and $\left.\mathrm{Fe}^{3+}\right)$, calcium $(\mathrm{Ca})$, phosphorus $(\mathrm{P})$, manganese $(\mathrm{Mn})$, boron (B), copper $(\mathrm{Cu})$, nickel $(\mathrm{Ni})$, lead $(\mathrm{Pb})$, zinc $(\mathrm{Zn})$, and cadmium (Cd) (Willett and Zarcinas, 1986; Franzen et al., 1999).

\section{Data Analysis and Model Selection}

All statistical analyses and graphics were performed using $\mathrm{R}$ version 3.2.2. (R Core Team, 2013). Soil temperature fluctuations from December 2014-December 2015 were plotted to assist in assessing the effects of soil temperature on soil $\mathrm{pH}$, soil moisture, soil chemicals, and vegetation regeneration. Principal component analysis (PCA) was used to test for relationships between the predictor variables: soil temperature, soil moisture, soil $\mathrm{pH}$, and soil chemical levels. The relationships between variables were plotted using a biplot to aid visual interpretation. We performed a least absolute shrinkage and selection operator (LASSO) (package lars) regression to drop variables with coefficients of zero and
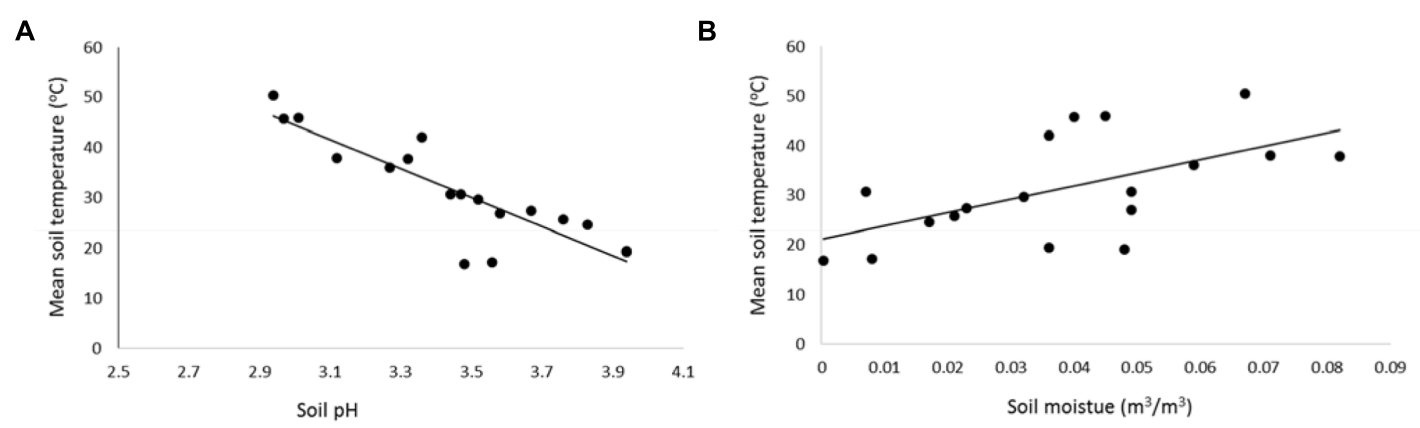

FIGURE 3 | Mean soil temperature at $\mathbf{1 5} \mathbf{~ c m ~ d e p t h ~ ( m e a s u r e d ~ a t ~ t h e ~ t i m e ~ o f ~ s o i l ~ d a t a ~ c a p t u r e ) ~ a s ~ a ~ f u n c t i o n ~ o f ~ ( A ) ~ s o i l ~ p H ~ ( ~} y=-28.81 x+130.84)$, and (B) volumetric soil moisture $(y=268.5 x+21), n=18$. Data captured at $15 \mathrm{~cm}$ depth $(n=18$, control: $n=3$, mid temperature: $n=8$, high temperature: $n=7)$, December 2014-December 2015. Data captured at Crown Road Geothermal Area. 

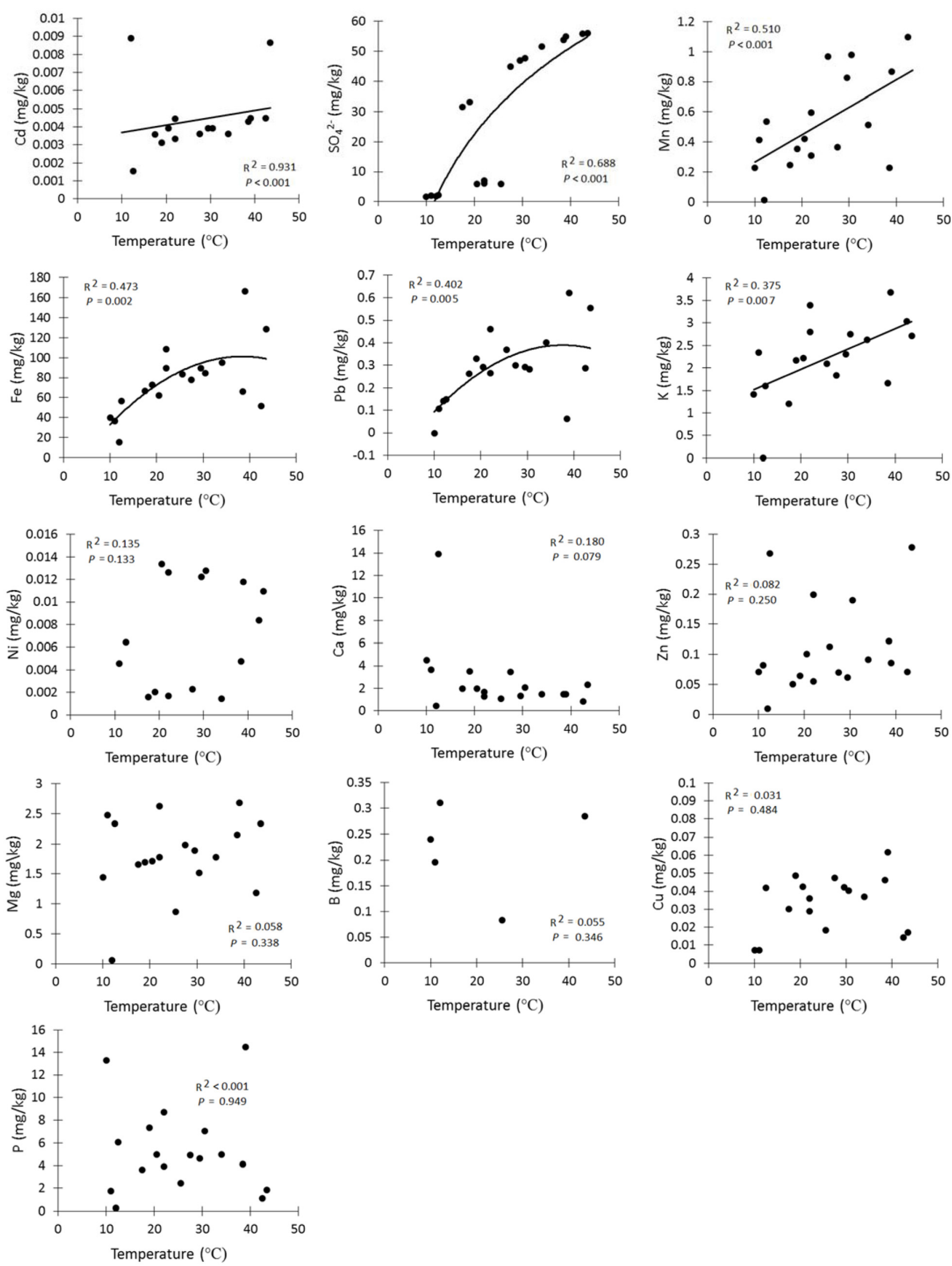

FIGURE 4 | Soil chemistry levels along a temperature gradient. 
reduce high dimensional data for the regression analysis and model selection. A simple linear regression analysis was run with each of the remaining predictor variables and either root biomass or vegetation regeneration as the response variable. Model selection was based on the Akaike's Information Criterion (AIC). The model with the lowest AIC score was selected. Since vegetation regeneration was collected as proportion data, a logit transformation (package logit) was applied prior to the regression analysis.

\section{RESULTS}

\section{Soil Temperature}

The continuously logged soil temperature readings at the closest site to the geothermal features ranged between 18.5 and $70^{\circ} \mathrm{C}$ and the readings at the coolest, most distant site ranged between 6.5 and $32^{\circ} \mathrm{C}$, from December 2014 to December 2015 (Figure 1). The soil temperature ranges of the high temperature plots were split into mid $\left(18-43^{\circ} \mathrm{C}\right)$ and high $\left(>56^{\circ} \mathrm{C}\right)$ temperate ranges. Table 1 lists mean soil temperatures, while Figure 2 shows the location of each plot with the study area.

\section{Soil Moisture and pH Value}

Acidic soil occurred where soil temperatures were highest, and the soil $\mathrm{pH}$ increased in a linear fashion with a decline in soil temperature (Figure 3; $t$-value $=9.08, P<0.001, R^{2}=0.75$ ). There was a significant increase in soil moisture with increasing soil temperature (Figure 3; $t$-value $=5.22, P=0.006, R^{2}=0.35$ ).

\section{Soil Chemistry}

Amongst the major elements, iron $\left(77.3 \pm 0.05 \mathrm{mg} \mathrm{kg} \mathrm{kg}^{-1}\right.$, mean \pm SE) and sulfate $\left(28.3 \pm 0.06 \mathrm{mg} \mathrm{kg}^{-1}\right)$ had the highest concentrations in the soil samples (Table 2). The rarest trace element was manganese $\left(0.6 \pm 3.8 \mathrm{mg} \mathrm{kg}^{-1}\right)$. In addition, lead $\left(0.3 \pm 12.5 \mathrm{mg} \mathrm{kg}^{-1}\right.$, mean $\left.\pm \mathrm{SE}\right)$ and nickel $(0.007 \pm 538$ $\mathrm{mg} \mathrm{kg}^{-1}$ ) had the highest concentrations of the trace elements. The linear regressions (Figure 4) indicated a strong positive relationship between soil temperature and $\mathrm{Cd}, \mathrm{SO}_{4}{ }^{2-}, \mathrm{Mn}$, $\mathrm{Fe}, \mathrm{Pb}$, and $\mathrm{K}$. However, there was no significant relationship detectable (Figure 4) between soil temperature and $\mathrm{Ni}, \mathrm{Ca}, \mathrm{Zn}$, $\mathrm{Mg}, \mathrm{B}, \mathrm{Cu}$, and $\mathrm{P}$. The biplot (Figure 5) collectively displays the correlation of all the tested soil elements with soil temperature, moisture and $\mathrm{pH}$; suggesting that soil temperature, soil moisture, $\mathrm{SO}_{4}{ }^{2-}, \mathrm{Mn}, \mathrm{Pb}, \mathrm{K}$, and $\mathrm{Fe}$ are closely related while soil $\mathrm{pH}$ shows a negative correlation with temperature.

\section{Vegetation Regeneration}

After applying the LASSO regression with vegetation regeneration as the response variable, the coefficients of all but two explanatory variables were zero. Amongst these two candidates, the model containing soil temperature as sole predictor variable had the lowest AIC. The regeneration coverage at the time of assessment ranged from 0 to $90 \%$ in individual plots. On average, the highest regeneration of around $55 \%$ was observed at the coolest soil temperature $\left(\mathrm{ca} .17^{\circ} \mathrm{C}\right.$ ) and declined in a curvilinear fashion with increasing soil temperature

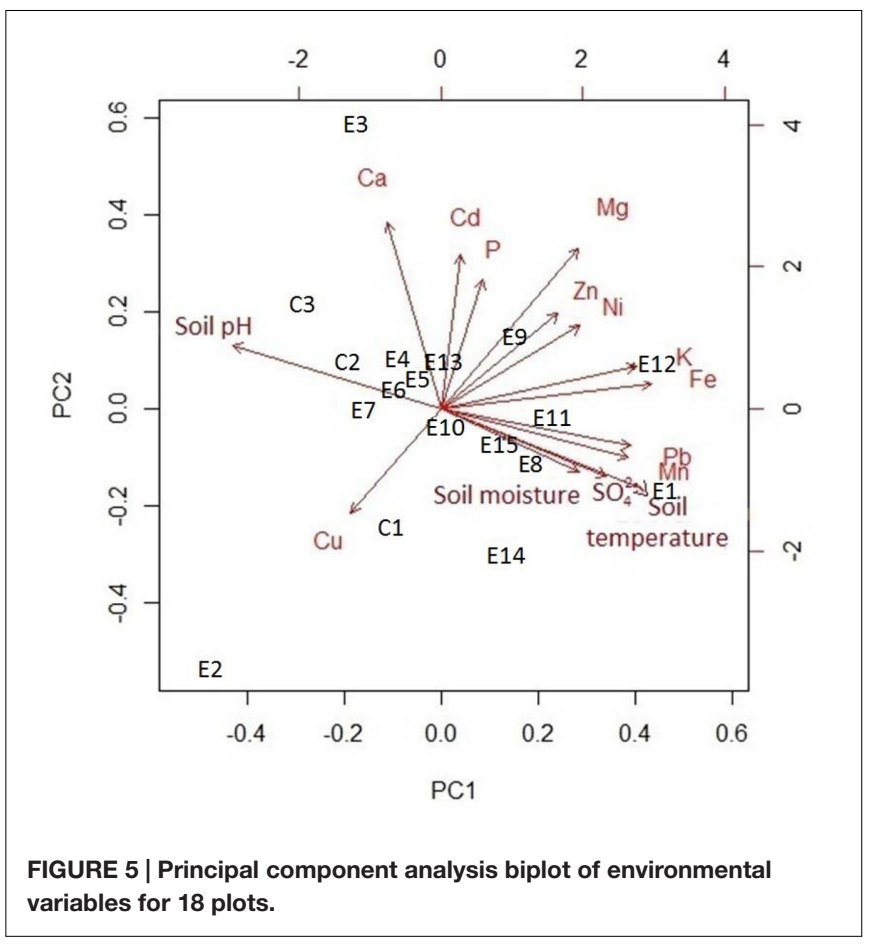

$\left(y=-1.45 x+71.5, P=0.012, R^{2}=0.34\right.$, Figure 6). The control plots with mean temperatures ranging from 16.7 to $19.2^{\circ} \mathrm{C}$ had vegetation coverage between 50 and $90 \%$. The intermediate plots with mean temperatures ranging from 20 to $38^{\circ} \mathrm{C}$ had vegetation coverage between 12 and $35 \%$ and the high temperature plots with mean temperature ranging from 42 to $50.4^{\circ} \mathrm{C}$ had vegetation coverage between 0 and $10 \%$.

\section{Root Biomass}

The same LASSO model, applied to root biomass data, showed again that soil temperature as sole predictor variable yielded the lowest AIC. The variation in total biomass was strongly negatively related to soil temperature (Figure 7). Overall, there were $70 \%$ more roots regardless of root diameter in the cores excavated from the cooler control plots than plots with higher mean temperature. The difference in biomass between control and high temperature plots was greatest $(243 \%)$ for fine roots $(<1.5 \mathrm{~mm})$ and decreased with increasing root diameter.

\section{DISCUSSION}

Understanding the impacts of soil warming on vegetation can help shape the conservation approaches of the future. This study, using geothermal heating, demonstrated the adverse effects of substantial soil warming on vegetation regeneration and root biomass. Our results indicate that after 1 year, two thirds of geothermally heated plots had vegetation regeneration of less than 35\%, while all control (ambient) plots showed a minimum of $50 \%$ regeneration. Similarly, the control plots had significantly more biomass in roots of $<0.5-3 \mathrm{~mm}$ in diameter. 


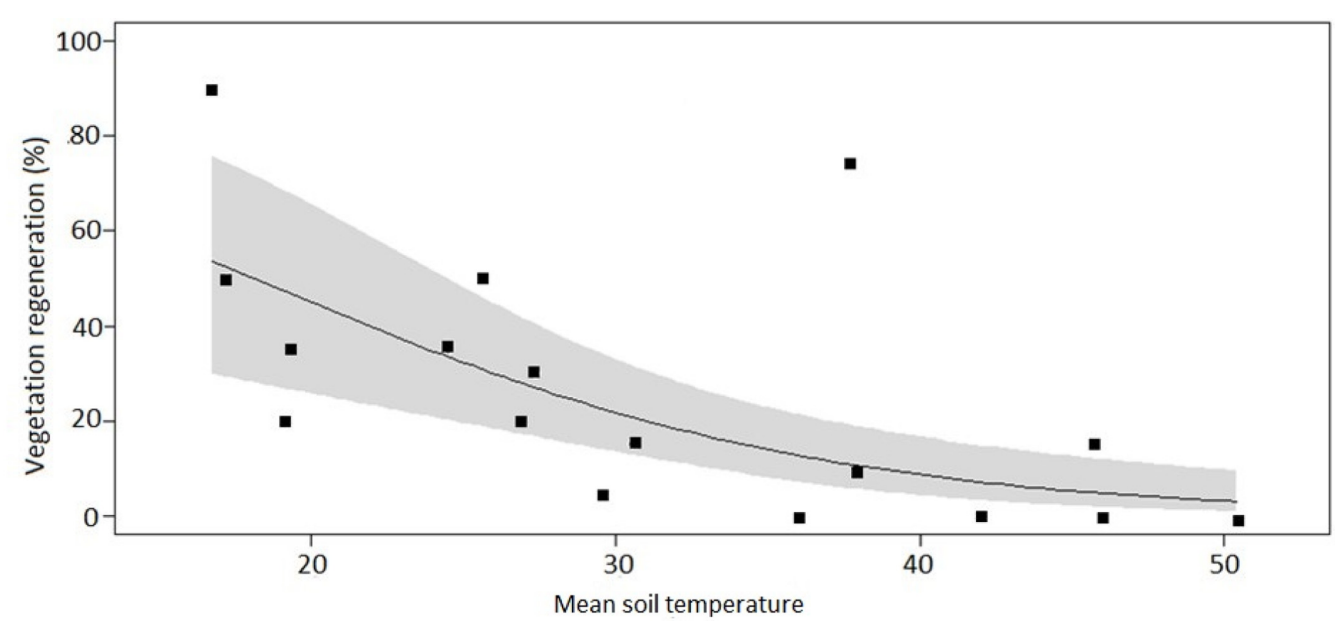

FIGURE 6 | Percentage vegetation regeneration cover across 18 plots spanning a soil temperature gradient at the Wairakei-Tauhara geothermal field. The solid line indicates the fit of a linear regression model with a logit-transformed response variable $\left(y=-1.45 x+71.5, P=0.012, R^{2}=0.34,\right)$. The gray-shaded area represents the $95 \%$ confidence interval.

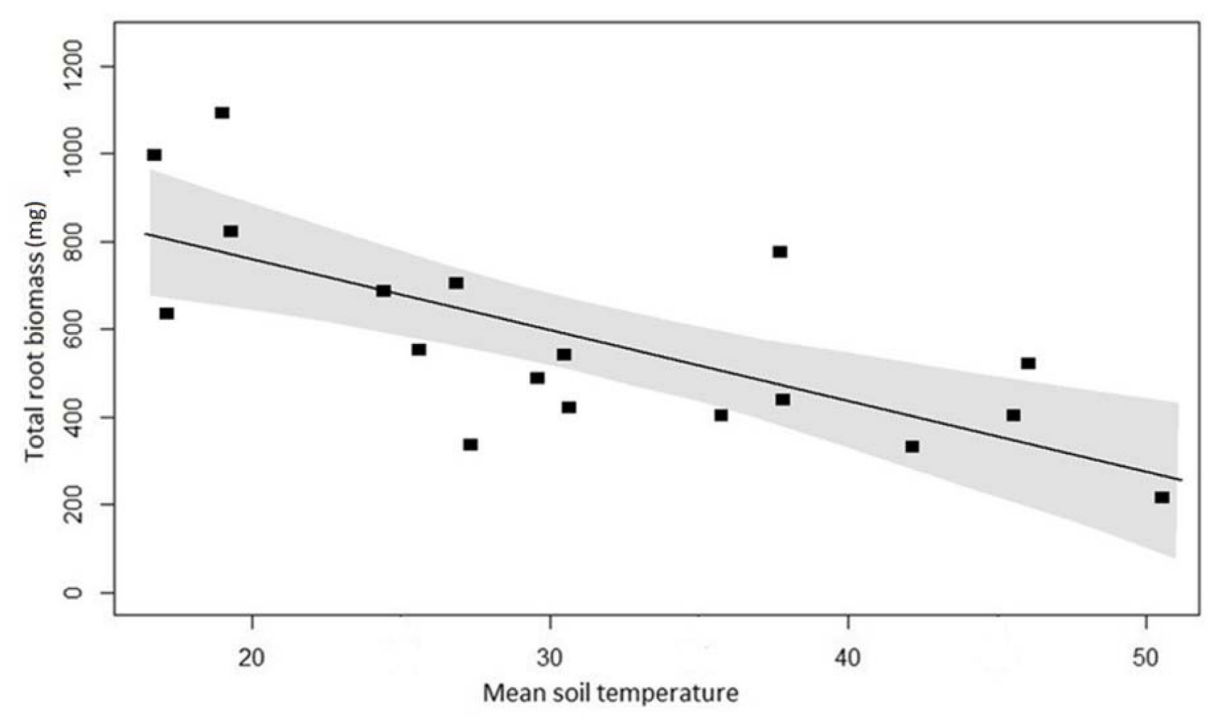

FIGURE 7 | Root biomass at 18 plots across the temperature gradient, with linear regression $\left(y=-15.9 x+1067.3, P<0.001, R^{2}=0.52\right)$. The area between the gray-shaded area represents the $95 \%$ confidence interval.

Our analyses showed that soil temperature is the dominating effect on vegetation regeneration and root growth. Previous studies have also suggested that in geothermal fields, vegetation establishment and growth is strongly controlled by thermal gradients; (Burns, 1997; Elmarsdottir et al., 2003; Muukkonen, 2006; Chiarucci et al., 2008; van Manen and Reeves, 2012), having fundamental effects on the abiotic and biotic processes determining the distribution and density of geothermal vegetation (Chapin, 1983; Saito et al., 2009; Aalto et al., 2013; Olefeldt et al., 2013). Apart from growth rates and community composition, soil temperature may also affect species-specific growth forms as is the case with the dominant woody species in our study system (Harris, 1996; Boothroyd, 2009; Beadel et al., 2012).

In this study we have presented evidence that slow regeneration of above- and below-ground biomass is primarily due to elevated soil temperature. The observed regeneration rates in our high temperature plots suggest that vegetation regeneration will be slow in the case of soil warming but will not halt. Most importantly, we showed a consistent increase in root and vegetation growth in control plots and much slower regeneration in the high temperature plots. Our findings fully support our hypothesis that warming negatively affects root productivity and total biomass. The correlations of soil 
temperature with soil moisture, $\mathrm{pH}$, and soil chemistry strongly suggest that soil warming will not only have a direct impact on vegetation by hindering development, but also indirectly by changing soil properties (Liu et al., 2015).

There was a positive relationship between soil temperature and soil moisture, which has also been shown in previous studies (Schmer and Werner, 1974; Idso et al., 1975; Pratt and Ellyett, 1979). This suggests that soil moisture content is geologically influenced in the same way as soil temperature (Legates et al., 2011; Wang et al., 2013). On the contrary, there was a negative relationship between soil temperature and soil $\mathrm{pH}$. The lower $\mathrm{pH}$ together with high soil temperature is an indication of geothermal fluid and fume discharges (Sudarman et al., 2000) containing a range of trace elements (Rodríguez, 2014). Such low soil pH levels seen in the study area could negatively influence plant growth and biomass (Lakkaraju et al., 2010; Al-Traboulsi et al., 2013).

The mineral content of the geothermal fluid is absorbed by the organic matter and clay minerals in the soil, which are responsible for elevated concentrations of a variety of elements (Nicholson, 2012). The elements present in the soil as well as their concentration depends on the geothermal system (Van Kooten, 1987; Murray, 1997). Different geothermal systems have varying levels of crustal heat flow that are related to the presence of hot rocks located deeper in the crust (Rybach, 1981; DiPippo, 2005) and with the transfer of geothermal heat to the surface by the convection of ground water (Helgeson, 1968; Renner et al., 1975; Reiter et al., 1978), different concentrations of elements are transported to the surface (Mahon, 1970). Our soil chemistry analyses identified $\mathrm{Fe}$ and $\mathrm{SO}_{4}{ }^{2-}$ as the most abundant chemical species ( $\mathrm{mg} / \mathrm{kg}$ ) amongst those tested. In a study of the Te Kopia Steamfield, New Zealand, Burns (1997) also noted high levels of extractable $\mathrm{SO}_{4}{ }^{2-}$ and $\mathrm{Fe}$. Although $\mathrm{Fe}$ is one of the most abundant metals in the earth's crust, its availability to plant roots is very low and it is largely driven by soil $\mathrm{pH}$. At lower $\mathrm{pH}, \mathrm{Fe}$ becomes more available for uptake by roots (Morrissey and Guerinot, 2009). Fe is essential for the plant's metabolic processes but in excess amounts, it can be toxic (Aznar et al., 2015). Elevated amounts of $\mathrm{SO}_{4}{ }^{2-}$ in soil can have inhibitory effects on the growth, photosynthesis, and survival of plants (Ferguson and Lee, 1983; Austin and Wieder, 1987). Similar to

\section{REFERENCES}

Aalto, J., Roux, P. C. L., and Luoto, M. (2013). Vegetation mediates soil temperature and moisture in arctic-alpine environments. Arct. Antarct. Alp. Res. 45, 429439. doi: 10.1657/1938-4246-45.4.429

Abramoff, R., and Finzi, A. (2014). "Are above and belowground phenology in sync?", in Symposium Conducted at the Meeting of the AGU Fall Meeting Abstracts, San Francisco, CA.

ACIA (2005). Arctic Climate Impact Assessment. Cambridge: Cambridge University Press.

Althoff, T. D., Menezes, R. S. C., de Carvalho, A. L., de Siqueira Pinto, A., Santiago, G. A. C. F., Ometto, J. P. H. B., et al. (2016). Climate change impacts on the sustainability of the firewood harvest and vegetation and soil carbon stocks in a tropical dry forest in Santa Teresinha Municipality, Northeast Brazil. For. Ecol. Manag. 360, 367-375. doi: 10.1016/j.foreco.2015.10.001
$\mathrm{SO}_{4}{ }^{2-}$, the presence of trace elements may also be indicative of high temperature geothermal systems (Mahon, 1970; Brondi et al., 1973). Levels of $\mathrm{Ca}, \mathrm{Fe}, \mathrm{K}, \mathrm{Mg}, \mathrm{Mn}, \mathrm{P}, \mathrm{B}, \mathrm{Cd}, \mathrm{Cu}, \mathrm{Ni}$, $\mathrm{Pb}$, and $\mathrm{Zn}$ found in this study environment are within the range reported for other geothermal systems (Ellis, 1970; Mahon, 1970).

\section{CONCLUSION}

Our findings indicates that soil temperature is the main factor responsible for a decline in root biomass and vegetation regeneration rate. This study provides an important baseline for warming experiments at geothermal sites to track effects of changing temperate conditions on the vegetation community. This information is essential to better comprehend and forecast changes in the structure and composition of plant communities and develop adaptive management plans. In future studies aimed at using geothermal warming to understand the effect of changing climatic conditions, areas with very moderate warming $\left(2-5^{\circ} \mathrm{C}\right)$ might be most suitable.

\section{AUTHOR CONTRIBUTIONS}

AN, SL, and BB conceived the idea. AN, SL, and MB developed the experimental design, $\mathrm{AN}$ and $\mathrm{MB}$ analyzed the data. JD conducted the soil chemistry data collection. AN wrote the manuscript, and all authors contributed to editing the final version.

\section{ACKNOWLEDGMENTS}

The authors would like to acknowledge Tauhara Middle 15 Trust who consented to this study being conducted on their land. The authors would also like to thank Peter Scott at SCION for his assistance with root analysis and John Robertson for assisting with the initial design and soil sampling. Thanks to Farrah Hiramis, Joan Dela-Cruz, and Huzaifa Mohsinally for assisting in the field and lab work.

Al-Traboulsi, M., Sjögersten, S., Colls, J., Steven, M., and Black, C. (2013). Potential impact of CO2 leakage from Carbon Capture and Storage (CCS) systems on growth and yield in maize. Plant Soil 365, 267-281. doi: 10.1007/s11104-0121390-5

Austin, K. A., and Wieder, R. K. (1987). Effects of elevated H+, SO42-, NO3- and $\mathrm{NH} 4+$ in simulated acid precipitation on the growth and chlorophyll content of 3 north American Sphagnum species. Bryologist 90, 221-229. doi: 10.2307/ 3242930

Aznar, A., Chen, N. W. G., Thomine, S., and Dellagi, A. (2015). Immunity to plant pathogens and iron homeostasis. Plant Sci. 240, 90-97. doi: 10.1016/j.plantsci. 2015.08.022

Balisky, A. C., and Burton, P. J. (1995). Root-zone soil temperature variation associated with microsite characteristics in high-elevation forest openings in the interior of British Columbia. Agric. For. Meteorol. 77, 31-54. doi: 10.1016/01681923(95)02235-P 
Beadel, S., Shaw, W., Bycroft, C., and Bawden, R. (2012). "Ecological assessment and sustainable management of geothermal vegetation in the Waikato region, New Zealand," in Proceedings of the New Zealand Geothermal Workshop 2012, Auckland.

Berg, B., Berg, M., Bottner, P., Box, E., Breymeyer, A., de Anta, R. C., et al. (1993). Litter mass loss rates in pine forests of Europe and Eastern United States: some relationships with climate and litter quality. Biogeochemistry 20, 127-159. doi: 10.1007/BF00000785

Betts, R. A. (2001). Biogeophysical impacts of land use on present-day climate: near-surface temperature change and radiative forcing. Atmos. Sci. Lett. 2, 39-51. doi: 10.1006/asle.2001.0023

Bibby, H., Caldwell, T., Davey, F., and Webb, T. (1995). Geophysical evidence on the structure of the Taupo Volcanic Zone and its hydrothermal circulation. J. Volcanol. Geothermal Res. 68, 29-58. doi: 10.1016/0377-0273(95)00 007-H

Bledsoe, C. S., Fahey, T. J., Day, F. P., and Ruess, R. W. (1999). Measurement of Static Root Parameters: Biomass, Length, and Distribution in the Soil Profile. Standard Soil Methods for Long-Term Ecological Research. New York, NY: Oxford University Press, 413-436.

Bond-Lamberty, B., Gower, S. T., Wang, C., Cyr, P., and Veldhuis, H. (2006). Nitrogen dynamics of a boreal black spruce wildfire chronosequence. Biogeochemistry 81, 1-16. doi: 10.1007/s10533-006-9025-7

Boothroyd, I., and Stark, J. (2000). "Use of invertebrates in monitoring," in New Zealand Stream Invertebrates: Ecology and Implications for Management, eds K. J. Collier and M. J. Winterbourn (Christchurch: New Zealand Limnological Society), 344-373.

Boothroyd, I. K. (2009). Ecological characteristics and management of geothermal systems of the Taupo Volcanic Zone, New Zealand. Geothermics 38, 200-209. doi: 10.1016/j.geothermics.2008.12.010

Brondi, M., Dall'Aglio, M., and Vitrani, F. (1973). Lithium as a pathfinder element in the large scale hydrogeochemical exploration for hydrothermal systems. Geothermics 2, 142-153. doi: 10.1016/0375-6505(73)90021-7

Burns, B. (1997). Vegetation change along a geothermal stress gradient at the $\mathrm{Te}$ Kopia steamfield. J. R. Soc. N. Z. 27, 279-293. doi: 10.1080/03014223.1997. 9517539

Burns, B., and Leathwick, J. R. (1995). Geothermal Vegetation Dynamics. Wellington: Department of Conservation.

Burns, B., Whaley, K. J., and Whaley, P. T. (1995). Thermotolerant Vegetation of the Tauhara Geothermal Field. Hamilton: Landcare Research.

Carón, M. M., De Frenne, P., Chabrerie, O., Cousins, S. A. O., De Backer, L., Decocq, G., et al. (2015). Impacts of warming and changes in precipitation frequency on the regeneration of two Acer species. Flora 214, 24-33. doi: 10. 1016/j.flora.2015.05.005

Chapin, F. III, and Körner, C. (eds) (1995). "Patterns, causes, changes, and consequences of biodiversity in arctic and alpine ecosystems," in Arctic and Alpine Biodiversity: Patterns, Causes and Ecosystem Consequences, (Berlin: Springer), 313-320. doi: 10.1007/978-3-642-78966-3_22

Chapin, F. S. III (1983). Direct and indirect effects of temperature on arctic plants. Polar Biol. 2, 47-52. doi: 10.1007/BF00258285

Chiarucci, A., Calderisi, M., Casini, F., and Bonini, I. (2008). Vegetation at the limits for vegetation: vascular plants, bryophytes and lichens in a geothermal field. Folia Geobot. 43, 19-33. doi: 10.1007/s12224-008-9002-0

Claussen, M., Kubatzki, C., Brovkin, V., Ganopolski, A., Hoelzmann, P., and Pachur, H. J. (1999). Simulation of an abrupt change in Saharan vegetation in the Mid-Holocene. Geophys. Res. Lett. 26, 2037-2040. doi: 10.1029/ 1999GL900494

Clinton, B. D. (2003). Light, temperature, and soil moisture responses to elevation, evergreen understory, and small canopy gaps in the southern Appalachians. For. Ecol. Manag. 186, 243-255. doi: 10.1016/S0378-1127(03)00277-9

de Valpine, P., and Harte, J. (2001). Plant responses to experimental warming in a montane meadow. Ecology 82, 637-648. doi: 10.1890/0012-9658(2001) 082[0637:PRTEWI]2.0.CO;2

Death, R., and Death, F. (2006). "Forestry effects on stream invertebrate communities," in The Pakuratahi Land Use Study, eds G. Eyles and B. Fahey (Napier: Hawke's Bay Regional Council).

DiPippo, R. (2005). Geothermal Power Plants: principles, Applications and Case Studies. Amsterdam: Elsevier.
Djebou, D. C. S., and Singh, V. P. (2015). Retrieving vegetation growth patterns from soil moisture, precipitation and temperature using maximum entropy. Ecol. Mod. 30, 10-21. doi: 10.1016/j.ecolmodel.2015.03.022

Ellis, A. J. (1970). Quantitative interpretation of chemical characteristics of hydrothermal systems. Geothermics 2, 516-528. doi: 10.1016/0375-6505(70) 90050-7

Elmarsdottir, A., Ingimarsdottir, M., Hansen, I., Olafsson, J. S., and Olafsson, E. (2003). "Vegetation and invertebrates in three geothermal areas in Iceland," in Symposium Conducted at the Meeting of the International Geothermal Conference, Reykjavík.

Ferguson, P., and Lee, J. (1983). The growth of Sphagnum species in the southern Pennines. J. Bryol. 12, 579-586. doi: 10.1179/jbr.1983.12.4.579

Franzen, D., Hofman, V., Cihacek, L., and Swenson, L. (1999). Soil nutrient relationships with topography as influenced by crop. Precis. Agric. 1, 167-183. doi: 10.1023/A:1009955707173

Given, D. R. (1980). Vegetation on heated soils at Karapiti, central North Island, New Zealand, and its relation to ground. N. Z. J. Bot. 18, 1-13. doi: 10.1080/ 0028825X.1980.10427227

Harris, W. (1996). Genecological aspects of flowering patterns of populations of Kunzea ericoides and K. sinclairii (Myrtaceae). N. Z. J. Bot. 34, 333-354. doi: 10.1080/0028825X.1996.10410699

Healy, J. (1992). Central Volcanic Region: Landforms of New Zealand, 2nd Edn. Auckland: Longman Paul.

Hedhly, A., Hormaza, J. I., and Herrero, M. (2009). Global warming and sexual plant reproduction. Trends Plant Sci. 14, 30-36. doi: 10.1016/j.tplants.2008. 11.001

Helgeson, H. C. (1968). Geologic and thermodynamic characteristics of the Salton Sea geothermal system. Am. J. Sci. 266, 129-166. doi: 10.2475/ajs.266.3.129

Henry, G., and Molau, U. (1997). Tundra plants and climate change: the International Tundra Experiment (ITEX). Glob. Change Biol. 3, 1-9. doi: 10. 1098/rstb.2012.0481

Hinzman, L., Bettez, N., Bolton, W. R., Chapin, F. S., Dyurgerov, M., Fastie, C., et al. (2005). Evidence and implications of recent climate change in northern Alaska and other arctic regions. Clim. Change 72, 251-298. doi: 10.1007/s10584-0055352-2

Hoang, V. T. (2010). Estimation of In-situ Thermal Conductivities from Temperature Gradient Measurements. Berkeley, CA: Lawrence Berkeley National Laboratory.

Idso, S., Schmugge, T., Jackson, R., and Reginato, R. (1975). The utility of surface temperature measurements for the remote sensing of surface soil water status. J. Geophys. Res. 80, 3044-3049. doi: 10.1029/JC080i021p03044

IPCC (2007). Climate Change 2007: The Physical Science Basis. Contribution of Working Group I to the Fourth Assessment Report of the Intergovernmental Panel on Climate Change, eds S. Solomon, D. Qin, M. Manning, Z. Chen, M. Marquis, K. B. Averyt et al (Cambridge: Cambridge University Press).

IPCC (2013). Working Group I Contribution to the IPCC Fifth Assessment Report. Climate Change 2013: The Physical Sciences Basis Summary for Policymakers, eds T. F. Stocker, D. Qin, G.-K. Plattner, M. Tignor, S. K. Allen, J. Boschung et al (Cambridge: Cambridge University Press).

Jonasson, S., Havström, M., Jensen, M., and Callaghan, T. (1993). In situ mineralization of nitorgen and phosphorus of arctic soils after perturbations simulating climate change. Oecologia 95, 179-186. doi: 10.1007/BF00323488

Kang, S., Kim, S., Oh, S., and Lee, D. (2000). Predicting spatial and temporal patterns of soil temperature based on topography, surface cover and air temperature. For. Ecol. Manag. 136, 173-184. doi: 10.1016/S0378-1127(99) 00290-X

Kershaw, K. A. (1985). Physiological Ecology of Lichens. Cambridge: Cambridge University Press.

Kirschbaum, M. U. (1995). The temperature dependence of soil organic matter decomposition, and the effect of global warming on soil organic C storage. Soil Biol. Biochem. 27, 753-760. doi: 10.1016/0038-0717(94)00242-S

Kissling, W., and Weir, G. (2005). The spatial distribution of the geothermal fields in the Taupo Volcanic Zone, New Zealand. J. Volcanol. Geothermal Res. 145, 136-150. doi: 10.1016/j.jvolgeores.2005.01.006

Kumar, D., and Shekhar, S. (2015). Statistical analysis of land surface temperaturevegetation indexes relationship through thermal remote sensing. Ecotoxicol. Environ. Saf. 121, 39-44. doi: 10.1016/j.ecoenv.2015.07.004 
Lakkaraju, V. R., Zhou, X., Apple, M. E., Cunningham, A., Dobeck, L. M., Gullickson, K., et al. (2010). Studying the vegetation response to simulated leakage of sequestered $\mathrm{CO} 2$ using spectral vegetation indices. Ecol. Inform. 5, 379-389. doi: 10.1016/j.ecoinf.2010.05.002

Lapenis, A., Henry, H., Vuille, M., and Mower, J. (2014). Climatic factors controlling plant sensitivity to warming. Clim. Change 122, 723-734. doi: 10. 1007/s10584-013-1010-2

Legates, D. R., Mahmood, R., Levia, D. F., DeLiberty, T. L., Quiring, S. M., Houser, C., et al. (2011). Soil moisture: a central and unifying theme in physical geography. Prog. Phys. Geogr. 35, 65-86. doi: 10.1177/0309133310386514

Legittimo, P. C., and Martini, M. (1989). The ecological significance of the coexistence of sulphur dioxide and hydrogen sulphide in volcanic fumaroles. Chem. Ecol. 4, 15-20. doi: 10.1080/02757548908035959

Liu, L., Hu, C., Yang, P., Ju, Z., Olesen, J. E., and Tang, J. (2015). Effects of experimental warming and nitrogen addition on soil respiration and $\mathrm{CH} 4$ fluxes from crop rotations of winter wheat-soybean/fallow. Agric. For. Meteorol. 207, 38-47. doi: 10.1016/j.agrformet.2015.03.013

Loetsch, F., and Haller, K. E. (1973). Forest Inventory, Vol. II. München: BLV Verlagsgesellschaft $\mathrm{mbH}$.

Lukewille, A., and Wright, R. (1997). Experimentally increased soil temperature causes release of nitrogen at a boreal forest catchment in southern Norway. Glob. Change Biol. 3, 13-21. doi: 10.1046/j.1365-2486.1997.00088.x

Luo, Y., Sherry, R., Zhou, X., and Wan, S. (2009). Terrestrial carbon-cycle feedback to climate warming: experimental evidence on plant regulation and impacts of biofuel feedstock harvest. Glob. Change Biol. Bioenergy 1, 62-74. doi: 10.1111/j. 1757-1707.2008.01005.x

Mahon, W. A. J. (1970). Proceedings of the United Nations symposium on the development and utilization of geothermal resources chemistry in the exploration and exploitation of hydrothermal systems. Geothermics 2, 1310-1322. doi: 10.1016/0375-6505(70)90449-9

Martin, R., Rodgers, K. A., and Browne, P. R. L. (2000). Aspects of the distribution and movement of aluminium in the surface of the Te Kopia geothermal field, Taupo Volcanic Zone, New Zealand. Appl. Geochem. 15, 1121-1136. doi: 10.1016/S0883-2927(99)00112-2

McGee, K. A. (1997). Impacts of Volcanic Gases on Climate, The Environment, and People. Reston, VA: United States Geological Survey.

Milchunas, D., and Lauenroth, W. (2001). Belowground primary production by carbon isotope decay and long-term root biomass dynamics. Ecosystems 4, 139-150. doi: 10.1007/s100210000064

Morrissey, J., and Guerinot, M. L. (2009). Iron uptake and transport in plants: the good, the bad, and the ionome. Chem. Rev. 109, 4553-4567. doi: 10.1021/ cr900112r

Munir, T., Perkins, M., Kaing, E., and Strack, M. (2015). Carbon dioxide flux and net primary production of a boreal treed bog: responses to warming and watertable-lowering simulations of climate change. Biogeosciences 12, 1091-1111. doi: 10.5194/bg-12-1091-2015

Murray, K. S. (1997). The use of soil Hg to delineate zones of upwelling in low-to-moderate temperature geothermal systems. Geothermics 26, 193-202. doi: 10.1016/S0375-6505(96)00039-9

Muukkonen, P. (2006). Conservation aspects of geothermal vegetation. Pac. Conserv. Biol. 12, 255. doi: 10.1071/pc060255

Nicholson, K. (2012). Geothermal Fluids: Chemistry and Exploration Techniques. Berlin: Springer Science \& Business Media.

Norby, R. J., and Jackson, R. B. (2000). Root dynamics and global change: seeking an ecosystem perspective. New Phytol. 147, 3-12. doi: 10.1046/j.1469-8137. 2000.00676.x

Oechel, W. C., Vourlitis, G. L., Hastings, S. J., and Bochkarev, S. A. (1995). Change in arctic $\mathrm{CO}^{\wedge} 2$ flux over two decades: effects of climate change at barrow, Alaska. Ecol. Appl. 5, 846-855. doi: 10.2307/1941992

Oelke, C., and Zhang, T. (2004). A model study of circum-Arctic soil temperatures. Permafrost Periglacial Process. 15, 103-121. doi: 10.1002/ppp.485

O'Gorman, E. J., Benstead, J. P., Cross, W. F., Friberg, N., Hood, J. M., Johnson, P. W., et al. (2014). Climate change and geothermal ecosystems: natural laboratories, sentinel systems, and future refugia. Glob. Change Biol. 20, 3291-3299. doi: 10.1111/gcb.12602

Okkonen, J., and Kløve, B. (2010). A conceptual and statistical approach for the analysis of climate impact on ground water table fluctuation patterns in cold conditions. J. Hydrol. 388, 1-12. doi: 10.1016/j.jhydrol.2010.02.015
Olefeldt, D., Turetsky, M. R., Crill, P. M., and McGuire, A. D. (2013). Environmental and physical controls on northern terrestrial methane emissions across permafrost zones. Glob. Change Biol. 19, 589-603. doi: 10.1111/gcb. 12071

Pickering, C. M., and Green, K. (2009). Vascular plant distribution in relation to topography, soils and micro-climate at five GLORIA sites in the Snowy Mountains, Australia. Aust. J. Bot. 57, 189-199. doi: 10.1071/ BT08133

Pinheiro, J., Bates, D., DebRoy, S., and Sarkar, D. (2015). R Core Team. nlme: Linear and Nonlinear Mixed Effects Models R package version 3.1-117. Vienna: R Foundation for Statistical Computing.

Pratt, D. A., and Ellyett, C. D. (1979). The thermal inertia approach to mapping of soil moisture and geology. Remote Sens. Environ. 8, 151-168. doi: 10.1016/ 0034-4257(79)90014-2

Pregitzer, K., and King, J. (2005). "Effects of soil temperature on nutrient uptake," in Nutrient Acquisition by Plants, ed. H. BassiriRad (Berlin: Springer), 277-310. doi: 10.1007/3-540-27675-0_10

R Core Team (2013). R: A Language and Environment for Statistical Computing. Vienna: R Foundation for Statistical Computing.

Reiter, M., Shearer, C., and Edwards, C. (1978). Geothermal anomalies along the Rio Grande rift in New Mexico. Geology 6, 85-88. doi: 10.1130/00917613(1978)6<85:GAATRG >2.0.CO;2

Renner, J., White, D., and Williams, D. (1975). "Hydrothermal convection systems. Assess. Geothermal Resour. U. S. 1975 726, 5-57.

Rixen, C., Freppaz, M., Stoeckli, V., Huovinen, C., Huovinen, K., and Wipf, S. (2008). Altered snow density and chemistry change soil nitrogen mineralization and plant growth. Arct. Antarct. Alp. Res. 40, 568-575. doi: 10.1657/15230430(07-044)[RIXEN]2.0.CO;2

Rodríguez, E. (2014). Review of H2S Abatement in Geothermal Plants and Laboratory Scale Design of Tray Plate Distillation Tower. MSc. thesis. Reykjavik University, Reykjavík.

Rustad, L., Campbell, J., Marion, G., Norby, R., Mitchell, M., Hartley, A., et al. (2001). A meta-analysis of the response of soil respiration, net nitrogen mineralization, and aboveground plant growth to experimental ecosystem warming. Oecologia 126, 543-562. doi: 10.1007/s004420000544

Rybach, L. (1981). "Geothermal systems, conductive heat flow, geothermal anomalies," in Geothermal Systems: Principles and Case Histories, eds L. Rybach and L. J. P. Mufller (New York. NY: John Wiley \& Sons Ltd), 3-36.

Sachtler, M. (1975). "Evaluation de la regeneracion arborea," in Actas del curso FAO/Finlandia de Entrenamiento en Inventario Forestal, Merida, 355-365.

Saito, M., Kato, T., and Tang, Y. (2009). Temperature controls ecosystem CO2 exchange of an alpine meadow on the northeastern Tibetan Plateau. Glob. Change Biol. 15, 221-228. doi: 10.1111/j.1365-2486.2008.01713.x

Schmer, F. A., and Werner, H. D. (1974). Remote sensing techniques for evaluation of soil water conditions. Trans. ASAE 17, 310-0314. doi: 10.13031/2013. 36847

Shaver, G. R., Canadell, J., Chapin, F. S., Gurevitch, J., Harte, J., Henry, G., et al. (2000). Global warming and terrestrial ecosystems. BioScience 50, 871-882. doi: 10.1641/0006-3568(2000)050[0871:GWATEA]2.0.CO;2

Shen, M., Tang, Y., Chen, J., Yang, X., Wang, C., Cui, X., et al. (2014). Earlierseason vegetation has greater temperature sensitivity of spring phenology in Northern Hemisphere. PLOS ONE 9:e88178. doi: 10.1371/journal.pone. 0088178

Smale, M. C., Fitzgerald, N. B., Mason, N. W. H., and Cave, S. A. (2009). Wairakei Geothermal Field Vegetation Monitoring:Changes After 12 Years. Lincoln: Landcare Research Contract Report.

Soengkono, S. (1995). A magnetic model for deep plutonic bodies beneath the central Taupo Volcanic Zone, North Island, New Zealand. J. Volcanol. Geothermal Res. 68, 193-207. doi: 10.1016/0377-0273(95)00013-K

Sudarman, S., Suroto, P. K., and Aspiyo, S. (2000). "Geothermal development progress in Indonesia: country update 1995-2000," in Proceedings of the World Geothermal Congress 2000, Kyushu-Tohoku.

Van Kooten, G. K. (1987). Geothermal exploration using surface mercury geochemistry. J. Volcanol. Geothermal Res. 31, 269-280. doi: 10.1016/03770273(87)90071-0

van Manen, S. M., and Reeves, R. (2012). An assessment of changes in Kunzea ericoides var. microflora and other hydrothermal vegetation at 
the Wairakei-Tauhara geothermal field, New Zealand. Environ. Manag. 50, 766-786. doi: 10.1007/s00267-012-9899-1

Villarreal, B., and Jesus, B. D. (2012). Effects of Climate Change and Urban Development on the Distribution and Conservation of Vegetation in a Mediterranean Type Ecosystem. M.S. thesis, Arizona State University, Ann Arbor, MI

Walck, J. L., Hidayati, S. N., Dixon, K. W., Thompson, K., and Poschlod, P. (2011). Climate change and plant regeneration from seed. Glob. Change Biol. 17, 2145-2161. doi: 10.1111/j.1365-2486.2010.02368.x

Walther, G.-R. (2010). Community and ecosystem responses to recent climate change. Philos. Trans. R. Soc. B Biol. Sci. 365, 2019-2024. doi: 10.1098/rstb.2010. 0021

Wan, S., Luo, Y., and Wallace, L. L. (2002). Changes in microclimate induced by experimental warming and clipping in tallgrass prairie. Glob. Change Biol. 8, 754-768. doi: 10.1046/j.1365-2486.2002.00510.x

Wang, C., Cao, R., Chen, J., Rao, Y., and Tang, Y. (2015). Temperature sensitivity of spring vegetation phenology correlates to within-spring warming speed over the Northern Hemisphere. Ecol. Indic. 50, 62-68. doi: 10.1016/j.ecolind.2014. 11.004

Wang, S., Fu, B., Gao, G., Liu, Y., and Zhou, J. (2013). Responses of soil moisture in different land cover types to rainfall events in a re-vegetation catchment area of the Loess Plateau, China. Catena 101, 122-128. doi: 10.1016/j.catena.2012. 10.006

Willett, I., and Zarcinas, B. (1986). Nitric acid dissolution and multi-element analysis of soils and sediments by inductively coupled plasma spectrometry. Commun. Soil Sci. Plant Anal. 17, 183-193. doi: 10.1080/00103628609367707

Zhang, X., Friedl, M. A., Schaaf, C. B., and Strahler, A. H. (2004). Climate controls on vegetation phenological patterns in northern mid-and high latitudes inferred from MODIS data. Glob. Change Biol. 10, 1133-1145. doi: 10.1111/j.1529-8817. 2003.00784.x

Conflict of Interest Statement: The authors declare that the research was conducted in the absence of any commercial or financial relationships that could be construed as a potential conflict of interest.

Copyright (c) 2017 Nishar, Bader, O'Gorman, Deng, Breen and Leuzinger. This is an open-access article distributed under the terms of the Creative Commons Attribution License (CC BY). The use, distribution or reproduction in other forums is permitted, provided the original author(s) or licensor are credited and that the original publication in this journal is cited, in accordance with accepted academic practice. No use, distribution or reproduction is permitted which does not comply with these terms. 